\title{
ICK wt Allele
}

National Cancer Institute

\section{Source}

National Cancer Institute. ICK wt Allele. NCI Thesaurus. Code C150262.

Human ICK wild-type allele is located in the vicinity of $6 \mathrm{p} 12.1$ and is approximately $61 \mathrm{~kb}$ in length. This allele, which encodes serine/threonine-protein kinase ICK protein, is involved in intraflagellar transport and ciliogenesis. Mutation of the gene is associated with endocrine-cerebroosteodysplasia and susceptibility to juvenile myoclonic epilepsy. 